\title{
Distortion of Content and Endangered Archives: A Case Study of a Donation to the American University of Beirut, Lebanon
}

\begin{abstract}
"The question of Archive is not [...] a question of past. It is not a question of concept dealing with the past that might already be at our disposal, an archivable concept of the archive. It is a question of the future, the question of the future itself, the question of an answer, of a promise and a responsibility for tomorrow."
\end{abstract}

\section{Introduction}

This paper aims to shed light on the challenges related to locating and accessing archival sources on Lebanon and tries to demonstrate the way political, administrative, and ethnic history can determine and justify their availability locally and regionally. It explores the various regimes that have influenced the shaping of the history of Lebanon and that have left a written legacy and archival collection related to that history.

This research paper also outlines the obstacles that can hinder access to such archival sources. Based on a case study of a collection of diplomatic archival materials donated to the American University of Beirut (AUB) in 2014, it examines the reshaping of this archival content to answer the following question: are "endangered" archives just documents and sources that suffered some kind of physical disaster? For more than 500 years, historical material related to the Middle East, including what is now the Republic of Lebanon, has suffered loss, damage, and dispersion, ${ }^{2}$ similar to archives from other countries that went through periods of war (a manmade disaster). ${ }^{3}$

\footnotetext{
1. Jacques Derrida. Archive Fever: A Freudian Impression (Chicago: University of Chicago Press, 1996), 29.

2. Lebanon has witnessed foreign intervention resulting in the constitution of administrations, which have generated correspondence in the form of reports, letters, diaries, and the like. Such documents have recorded the geopolitical and administrative constitution of the region.

3. Laila Hussein Moustafa, "Endangers Culture Heritage: A Survey of Disaster Management Planning in Middle East Libraries and Archives," Library Management 36, no. $6 / 7$ (2015), 476-94. doi:http:/ / dx.doi.org/10.1108/LM-04-2015-0010.
}

*(C) 2017 by Mariette Atallah (CC BY-NC [https://creativecommons.org/licenses/by-nc/4.0/]). 


\section{Historical Sources and Challenges Regarding Availability of Archival Sources \\ The Ottoman Empire: History}

From the beginning of the sixteenth century until 1915, Lebanon, like other regions in the Middle East, was part of the Ottoman Empire. During this period, Lebanon witnessed three regional administrations, each generating a written legacy and archives. ${ }^{4}$

- The Emirate: The period extending from the second half of the sixteenth century until 1841 can be characterized by relative independence, where Mount Lebanon was ruled by local emirs. ${ }^{5}$ To govern the various regions of the country, the emir, who held the title of häkim (governor), was assisted by chiefs, emirs, or sheikhs who had inherited their posts from their forefathers.

- The Qá'immaqāmat: From 1842 to 1860, Lebanon was divided into two administrative divisions ( $Q \bar{a}$ ' $i m m a q a \bar{a} m a t)$, each headed by an acting governor, or $Q \bar{a}$ ' $i m m a q a \bar{a} m$, appointed by the Ottoman sultan from among members of a designated family. During these periods, archival materials, including those related to official transactions, remained the personal property of the holder, and many such documents were often destroyed, burned, or damaged by insects or vermin. ${ }^{6}$

- The Mutasarrifiyya is known also as the Autonomy Trust. During the period from 1861 until World War I, each district was governed by a pasha nominated by the Ottoman Sultan. During this period, official archives were produced, and decisions of the Board were recorded in special registers that belonged to the government.

\section{Challenges}

Loss, damage, and dispersion of family and local administrative archives are the main obstacles that hinder access to these "private" collections. The main reason arises from a cultural barrier: many archive holders, unaware or ignorant of the historical value of such material, often disposed of bulky documents or simply let them fall into disrepair.

4. Maurice Chehab, "Les archives historiques du Liban," in Les Arabes par leurs archives: XVIe-XXe siècles, eds. Jacques Barque and Dominique Chevallier (Paris: Centre National de la Recherche Scientifique, 1976), 55-62. For more details about the Lebanese history in the nineteenth century, check Karam Rizk, Le Mont-Liban au XIXe siècle: de l'Emirat au Mutasarrifiya: tenants et aboutissants du Grand-Liban (Kaslik: Université Saint-Esprit de Kaslik, 1994) and Edmond Rabbath, La formation historique du Liban politique et constitutionnel: Essai de synthèse (Beyrouth: Impr. catholique, 1986).

5. Giovanni Fontana Antonelli. Liban: mise sur pied d'un service national d'archives et de pré-archivage [report of mission], ([s.1.], UNESCO, 1974), available online at http:/ / unesdoc.unesco.org/ images / 0001/000120/012020fb.pdf [accessed 11 January 2017].

6. Chehab, "Les archives historiques du Liban," in Les Arabes par leurs archives: XVIe-XXe siècles, 56. 
Archival materials produced by the Ottoman government, kept at the General Directorate of State Archives at the Prime Ministry of the Republic of Turkey, ${ }^{7}$ were written in the Turkish language, as well as in a combination of Turkish, Arabic, and Persian. Thus, to explore the Ottoman archives, language often proves a difficulty. The terminology used in the archives may pose an additional challenge; hence, translating such documents into a more accessible and common language ${ }^{8}$ is important. Furthermore, restriction on access of certain sensitive documents, as for example those pertaining to the 1860 War of the Mountain, is another obstacle.

Between 1955 and 1970, an initiative to collect archival material on Lebanon dating from the period of the Ottomans was undertaken by (Emir) Maurice Chehab. Historian, founder, and head of the General Directorate of Antiquities (DGA) for over thirty years, ${ }^{9}$ Chehab was a pioneer in collecting local administrative registers and archives of former political families. Led by Chehab, the DGA attempted to build an inventory of the available items; however, this was halted due to the outbreak of the civil war in 1975. For security reasons, the DGA's archives were moved from the DGA premises, located on the demarcation line dividing the capital city of Beirut, to the Beiteddine Palace in the Chouf mountains southeast of the city. ${ }^{10}$ These archives subsequently were seized from the palace by Druze militias and only restored to the Lebanese State in 1999. It is unclear whether they were returned to the DGA in their entirety and, due to a lack of funds, thousands of files have not been inventoried and remain inaccessible to researchers.

\section{The French Mandate: History}

At the end of World War I and with the partitioning of the Ottoman Empire, Lebanon came under French mandate from 1920 to 1943. The State of Greater Lebanon was created, adding to Mount Lebanon the areas of North Lebanon, South Lebanon, and the Bekaa. During this period, the French officials within the former Ottoman Empire, and particularly in Lebanon, produced a massive quantity of documents that

7. For more information, check the General Directorate of State Archives in the Prime Ministry of the Republic of Turkey's official website, available online at http:/ / en.devletarsivleri.gov.tr/ [accessed 7 January 2017].

8. For more details about the translation of the Ottoman archives related to the Arab world, see Lutfi Manal, "History of the Arabs in the Ottoman Archives," Asharq Al-Awsat (2008), available online at www.turkishculture.org/general/museums/ottoman-archives/history-of-arabs-772.htm?type=1 [accessed 10 January 2017].

9. Euromed Heritage: Strengthening of Institutional and Legal Frameworks: Workshop on Inventories [conference proceedings], 10-12 December 2008, UNESCO Headquarters, Paris, France, available online at www.euromedheritage.net/euroshared/doc/actes.pdf [accessed 3 January 2017].

10. Some archeological objects were placed in the underground chambers of the Crusader castle in Byblos, others were shipped to the French Archaeological Institute in Damascus. For more details, see Selma al-Radi, "War and Cultural Heritage: Lessons from Lebanon, Kuwait and Iraq," in The Power of Culture (2003), available online at www.krachtvancultuur.nl/actueel/2003/oktober/war_and_cultural_ heritage.html [accessed 5 November 2016]. 
were addressed to the French Ministry of Foreign Affairs. ${ }^{11}$ Political and commercial correspondence was held at consular posts in the former Ottoman Empire and in the Arab provinces, at embassies, consulates, and the office of French representatives to international organizations and commissions. Sources related to the French Mandate period also can be found at the National and Diplomatic Archives in Paris, at the Repatriated Archives of the French consulates in Arab provinces of the Ottoman Empire in Nantes, ${ }^{12}$ and in the diplomatic archives of other countries concerned (among them Austria, Great Britain, Italy, Russia, Spain, Turkey, and Germany). ${ }^{13}$

\section{Challenges}

Access to archival sources kept in France is regulated under legislation of the Ministry of Foreign Affairs. Some archival documents fall under restricted access, as stipulated in ministerial decree number $80-975$, article $8 .{ }^{14}$ For researchers, traveling costs and permission to access archives in other countries can pose a geographical barrier. This restriction, to a certain extent, might be mitigated by digital access; however, because most archives use a relatively broad classification scheme, it is usually necessary to access a sought collection in person to locate a specific document. Moreover, due to their volume-approximately 4,500 boxes relating to the Arab world alone - a major part of these archives has not yet been digitized; hence, the cost of microfilm (which varies from a symbolic amount for already digitized records to a substantial cost $)^{15}$ is borne by the researcher.

Archival material in Lebanon from the French Mandate period-excluding sources held at the National Archives ${ }^{16}$ - is in a critical situation. For example, the archives of the Railway and Public Transport Authority (RPTA), in spite of an ongoing project

11. Antoine Hokayem, Les provinces arabes de l'empire ottoman aux archives du ministère des affaires étrangères de France: 1793-1918 (Beyrouth: Les éditions universitaires du Liban, 1988), xi.

12. France. Ministry of Foreign Affairs, Accéder aux centres des archives diplomatiques, available online at www.diplomatie.gouv.fr/fr/archives-diplomatiques/acceder-aux-centres-des-archives-diplomatiques / [accessed 3 February 2017].

13. Adil Ismail, Documents diplomatiques et consulaires relatifs à l'histoire du Liban et des pays du ProcheOrient du XVII siècle à nos jours. Première partie. Les sources françaises. [Nouvelle série], Correspondance consulaire et commerciale, vol. 1 (Beyrouth: Editions des œuvres politiques et historiques, 1982).

14. France. Ministry of Foreign Affairs, Decree $n^{\circ} 80-975$ of December 1, 1980, Clause 8, abrogated by Executive order $n^{\circ} 2009-857$ of July 8, 2009, art. 2, Communicability of the archival sources of the Ministry of Foreign Affairs, Légifrance, le service public de l'accès au droit, available online at https: / / www. legifrance.gouv.fr/affichTexteArticle.do;jsessionid=3EB34C3892710CB8519022E249515A6E.tpdila08v_1 ?cidTexte $=$ JORFTEXT000000862714\&idArticle $=$ LEGIARTI000006427304\&dateTexte $=20110526 \& \mathrm{categ}$ orieLien=id\#LEGIARTI000006427304 [accessed 9 January 2017].

15. For more details, see France. National Archives, Practical information: Copy and reuse, available online at www.archives-nationales.culture.gouv.fr/web/guest/reproduire-un-document [accessed 12 January 2017].

16. The Constitutional Decrees of the Lebanese Government during the French Mandate can be found. These were restored in 1979 from the National Library, seriously damaged during the civil war. The collection also includes 1588 manuscripts and portraits of Lebanese intellectuals, which adorned the reading room, films and journals (first and special issues), a complete set of the Lebanese official gazette, official documents of the Lebanese Republic, postcards, and so on, as mentioned during a meeting with Ibrahim Assi, interim head of the National Archives' Library. Access is granted on demand. 
sponsored by the United Nations and the Train-Train, a local nongovernment organization preserving Lebanese railway heritage, ${ }^{17}$ are abandoned in most unsuitable conditions. Around 500 boxes containing railway maps commissioned during the French Mandate period by foreign companies, as well as correspondence, passenger tickets, medical records of workers, and so forth, remain in a precarious situation, stored on premises that are most inappropriate and unsuitable for their preservation.

\section{Lebanon since Independence in 1943: History \& Challenges}

Independence was declared and the Republic of Lebanon was proclaimed three years prior to the final withdrawal of French troops in $1946 .{ }^{18}$ Documents related to this period are held by Lebanese governmental institutions. The main problem with accessing such records is decentralization, as archival collections are held and maintained by each individual municipality and most municipalities have no inventories. For example, at the municipality of Jounieh (16 km north of Beirut), around 600 jute bags of records are waiting to be processed; and, to access the archival collection at the municipality of Sidon (40 km south of Beirut), a researcher needs to travel there in person.

\section{Additional Sources of Archives}

In addition to the sources of official documents and government archives discussed above, there are three main entities that have produced and now hold archival sources; namely, the audiovisual media, the written press, and the religious institutions.

- Audiovisual Media. The government-controlled radio and television stations Radio Orient and Télé Liban were founded in $1938^{19}$ and $1959,{ }^{20}$ respectively, and are under the directive of the Ministry of Information. Given the uniqueness of the archival material available, its scarcity, and the importance of the period covered in the history of the country, conversion from an obsolete format, which in most cases makes access nearly impossible, is imperative. The majority of these stations are owned and operated by political parties. Their aim is to promote a political agenda through broadcasting their respective opinions and beliefs. Access to the archives of such political and cultural media sources are through each affiliated organization.

17. Project of Capacity Development of the RPTA, sponsored by United Nations Development Programme (UNDP) and Train-Train. See http:/ / daleel-madani.org/profile/train-train [accessed 2 January 2017].

18. Boutros Dib, Histoire du Liban des origines au XXe siècle (Paris: Philippe Ray, 2006), 859-91; Philippe Khoury, Lebanon in History: From the Earliest Times to the Present (London: Macmillan, 1967), 486-96; Adil Ismail, Lebanon: History of a People, trans. Shereen Khairallah (Beirut: Dar al-Makchouf, 1972), 215-22.

19. Antoun al-Baytar, al-Sihāfah adwā' 'alá al-tārìkh (Bayrūt: Dār wa-Maktabat al-Turāth al-Adabī, 2012), 58.

20. Télé Liban: Télé Liban’s Journey, 1957-2017, available online at www.teleliban.com.lb/about [accessed 7 January 2017]. 
- Written Press. Due to strict censorship during the later reign of the Ottomans, ${ }^{21}$ numerous newspapers then chose to publish abroad. ${ }^{22}$ After the fall of the Ottoman Empire, the Lebanese press reflected the intellectual renaissance in the Middle East; today, collections of unique and rare serials are to be found in academic libraries worldwide. An initiative to provide comprehensive information regarding the location and availability of serials of specific interest to Middle Eastern studies is in progress through the Online Access to Consolidated Information on Serials (OACIS) system to be launched in 2017-2018. ${ }^{23}$

- Religious Institutions. In Lebanon, as in Islamic countries, religious, legal, and judicial authorities have been linked for many centuries. As examples, a branch of the Islamic Awqaf ${ }^{4}$ and legal experts, or Ifta ${ }^{25}$ clerks, are attached to the presidency of the Council of Ministers; muftis are paid by the government and directly overseen by the prime minister; and Muslim religious courts and judges (qadi) ${ }^{26}$ have jurisdiction over family law (marriage, divorce, affiliation, inheritance, and the like), though a verdict issued in a given case must be ratified by the civil courts of the state to be recognized. This close link between government and Islamic institutions underscores the vital importance of the documentation kept at the Houses of Fatwa and Awqaf, mosques, and Muslim courts. ${ }^{27}$ Similarly, the Maronite Patriarchate (Christian patriarchates, monasteries and churches, monks and clerks) also has kept track of correspondence with spiritual and civil leaders. Statistics and documents related to Catholic schools and missionary organizations, as well as other manuscripts, have been preserved at Christian institutions. ${ }^{28}$ Though these independent and private archives tend to be the best organized at the national level, ${ }^{29}$ the language used in many of the documents may prove an obstacle for researchers. Knowledge of

\footnotetext{
21. Ibid, 17.

22. In Paris, North and South America, England, Germany, Spain, Italy, and Brazil.

23. Previously maintained at Yale University Library (YUL), it was transferred to the AUB University Libraries in 2013-14; see http:/ / oacis.aub.edu.lb [accessed 3 February 2017].

24. Plural of Waqf; an endowment made by a Muslim to a religious, educational, or charitable cause, available online at https:/ / en.oxforddictionaries.com/definition/waqf. [accessed 11 January 2017].

25. Act of issuing a fatwa (legal opinion) by an authoritative consultant in matters of law, available online at www.oxfordislamicstudies.com/article/opr/t125/e978 [accessed 16 December 2016].

26. A judge in a Muslim community whose decisions are based on Islamic religious law, available online at http: / / dictionary.infoplease.com/ qadi [accessed 11 January 2017].

27. Antonelli, Liban: Mise sur pied d'un service national d'archives et de pré-archivage, 6. For availability of archives in other Lebanese institutions, also check Hassan Hallak, al-Arshif wa al-wathaiq wa al-makhtutat fi maktabat wa marakez lubnan wa al-aalam al-arabi: daleel al-bahith ila wathaiq al-bahth al-ilmi (Beirut: Dar annahda al Arabiya, 2003), 16-17.

28. Ibid., 134.

29. Several monastic orders are in the process of centralizing their archives by transferring sources and material from monasteries to educational institutions. Although not as yet available to the public, these archives are kept by centers for higher education affiliated with each respective order: archives of the Lebanese Maronite Order are held at the Holy Spirit University of Kaslik (USEK); those of the Mariamites Maronite Order at the Notre Dame University (NDU); and those of the Greek Orthodox monasteries at Balamand University.
} 
Syriac, spoken by some Christian communities in Syria and Mesopotamia during the Ottoman Era, and Garshuni, ${ }^{30}$ the writing of Arabic using the Syriac alphabet, are essential to accessing many manuscripts and documents stored in monasteries and patriarchates.

Certainly, a vast number of volumes of archival documents relating to Lebanon that were produced locally and regionally are closely linked to the political, administrative, and ethnic history of the country, but several factors hinder access to these archival sources.

\section{Content Distortion}

In addition to the difficulties in accessing archives as described, a significant obstacle to be considered when accessing archival sources is distortion of content, referring to situations when archival materials have been altered from their original state, a process that might occur during the initial or subsequent publication of a collection. This problem is explained below, through a case study of a particular donation received by the American University of Beirut University Libraries (AUB-UL) in 2014.

\section{The Collection}

The Hekmat Kassir ${ }^{31}$ donation, comprising 250 print volumes and 500 microfilm reels from French diplomatic archives, was presented to the AUB-UL in March 2014. Abdo Kassir, son of the donor, Hekmat Kassir, informed AUB-UL that the collection was composed of copies his father made from the French National Archives for his own cultural center of documents. The majority of the boxes containing print volumes and documents carried labels mentioning the name "Adel Ismail." Ismail, a former ambassador and permanent delegate to UNESCO, coauthored two sets of monographs with Maurice Chehab ${ }^{32}$ (mentioned previously in this paper) between 1975 and 1983.

Hekmat Kassir had permitted Ismail access to some of these documents, which were published by Ismail as working papers. However, questions have arisen regarding the

30. The writing of Arabic in letters of the Syriac alphabet, practiced mainly during the fourteenth century. See Joseph Moukarzel, "Le Garshuni. Remarques sur son histoire et son évolution," in Scripts Beyond Borders: A Survey of Allographic Traditions in the Euro-Mediterranean World, eds. J. Den Heijer, A. Schmidt, and T. Pataridze (Belgium: Peeters, 2014), 107-38.

31. Born in 1920, Hekmat Kassir is a Lebanese businessman who has lived in Africa and Paris. His $\mathrm{CV}$ indicates that he has published several books authored by Lebanese, French, and Arab officials and diplomats. For more details, see http:// goo.gl/tp87ms [accessed 9 January 2017].

32. Adil Ismail, Documents diplomatiques et consulaires relatifs à l'histoire du Liban et des pays du ProcheOrient du XVII siècle à nos jours, 37 vols. (Beyrouth: Editions des œuvres politiques et historiques, 1975 1994). The publication of this thirty-seven volume set was followed by a four volume set: Adil Ismail, Documents diplomatiques et consulaires relatifs à l'histoire $d u$ Liban et des pays $d u$ Proche-Orient $d u$ XVII siècle à nos jours. Première partie. Les sources françaises. [Nouvelle série], Correspondance consulaire et commerciale, 4 vols. (Beyrouth: Editions des œuvres politiques et historiques, 1982-[1983]). 
way Ismail had accessed the archives and documents for publication, and subsequently whether the AUB-UL had the right to accept this collection, especially because in the preamble to the first volume ${ }^{33}$ of the first set of Documents diplomatiques et consulaires relatifs à l'histoire du Liban et des pays du Proche-Orient du XVII siècle à nos jours, Chehab stated that "the precious documents collected for our National Archives by Ambassador Adil Ismail constitute a contribution that will enrich the history of Lebanon [... and] we have provided the necessary means so he [could] carry out this task."

To verify that the collection was not part of the DGA archives gathered by Chehab, this author contacted Suzie Hakimian, former curator at the National Museum, Beirut, and assistant to Chehab at that time, and Anne-Marie Afeich, present curator. They confirmed that Chehab had funded the publication of the documents but not the digitization process. Moreover, Abdo Kassir, son of the donor, Hekmat Kassir, explained: "My father funded the project and part of the findings was published by Ismail [,] but the originals were my father's property," he confirmed in an e-mail received on October 17, 2014. ${ }^{34} \mathrm{~A}$ document written by the donor and enclosed within the collection describes an estimated 300 additional reels of microfilm that had been offered by Ismail to the Ministry of Education but never were processed or made available to researchers, which suggests a certain level of negligence in the handling of archival material related to the history of Lebanon.

\section{The Controversy}

Among the sources in the 2014 donated collection were two large files of diplomatic archival records that Ismail had transcribed, along with his editorial note and annotations. They comprise small sections of both his 37-volume published series of diplomatic documents and his later 4-volume series. In these documents, some paragraphs had been crossed out or removed — covered with glued-on blank slips of paper. ${ }^{35}$ Ismail appears to reshape the text by suppressing the Christian presence in the events that the French diplomatic documents were describing.

These alterations reawakened an old controversy between Dr. Ismail and Dr. Antoine Hokayem, professor of contemporary history at the Lebanese University. ${ }^{36}$ In 1980, Hokayem signed and published a 60-page pamphlet ${ }^{37}$ criticizing Ismail's work.

33. Adil Ismail, Documents diplomatiques et consulaires relatifs à l'histoire du Liban et des pays du ProcheOrient du XVII siècle à nos jours, vol. 1 (Beyrouth: Editions des œuvres politiques et historiques), xii.

34. Abdo Kassir also emphasized during a phone conversation on October 17, 2014, that it is upon Hikmat Kassir's suggestion, and personal acquaintance of Dr. Ismail, that some of these documents served as working papers to Dr. Ismail.

35. It should be noted that, in order not to damage the document, it was not possible to remove the glued paper concealing this paragraph; however, the original text was clearly readable in transparency.

36. While researching this paper, the author contacted Hokayem to confirm his claim of censorship.

37. Antoine Hokayem, Etude critique sur les documents diplomatiques et consulaires de Adel Ismail. (Beirut: [s.n.], 1980). 
In his criticism, Hokayem gave proof of text manipulation, including truncated strings of characters, when comparing the original documents at the French National Archives and the selection published by Ismail in his 37-volume set. In this pamphlet, Hokayem stated that Ismail misled readers by failing to indicate- through the use of brackets and dots (...) or other symbols_-omitted words, phrases, or segments of text, although in his introduction to Etude critique sur les documents diplomatiques et consulaires de Adel Ismail, Ismail clearly stated that the documents had been published "in extenso"-in full, complete, and in their original content. ${ }^{38}$

Hokayem questioned the criteria Ismail had used, describing the selection of documents as "arbitrary" or even "directed." He claimed that Ismail suppressed paragraphs with a Christian connotation (Church, Mass celebration or Holy See, and the like). In his defense, Ismail stated that selection had been inevitable due to the vast quantity of documents; he also claimed that this practice is similar to the British government's so-called The White Book, where selective collections of documents are published by the government. Ismail accused Hokayem of attacking him for political reasons, confessional differences, and professional rivalry. In his answer to Ismail's argument, Hokayem stressed that governments do practice censorship only as authorities producing their own documents.

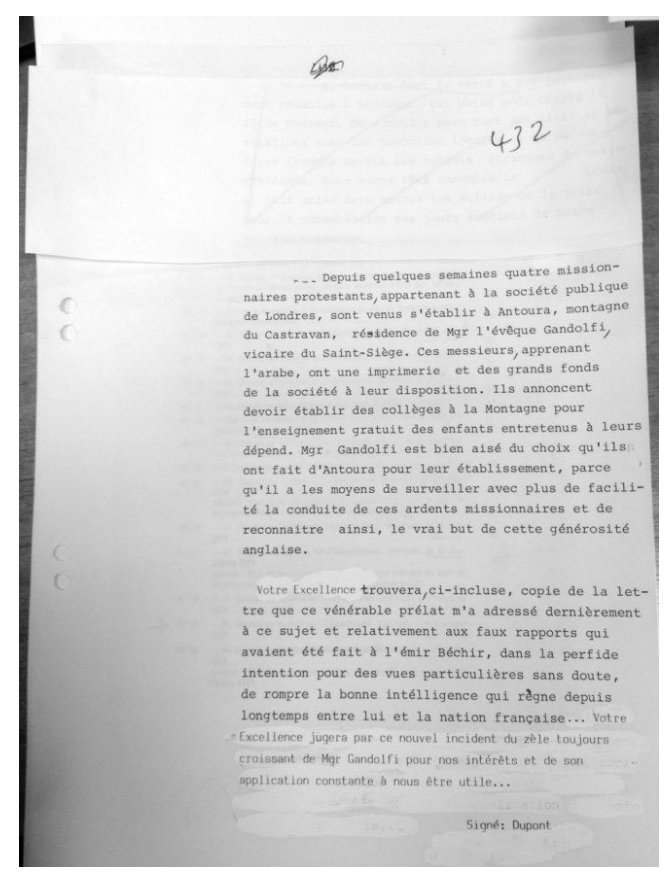

Similar to what Hokayem stated, when analyzing the 2014 donation, the name of Saint Louis, who led the Seventh Crusade to the Holy Land (1248-1254), as well as the terms "prayers" and "churches," are missing in the first document. However, the part that was omitted in Ismail's previous transcription was reintegrated in the printed version.

Image 1. The first document transcribed by Ismail. ${ }^{39}$ One paragraph was deleted by Ismail (where you see "432"). It was covered in a white paper but readable through transparency.

38. Candice Raymond, "Matière à controverse, Ateliers d'anthropologie, 36 (2012), doi:https:/ /ateliers. revues.org/9042?lang=en.

39. Archives de Nantes, consulat de Beyrouth, carton no. 8, Dépêche no. 16. M. Dupont, Drogman, gérant de consulat à Beyrouth, au vicomte de Chateaubriand, ministre des affaires étrangères. Beyrouth, le 8 Décembre 1823. 


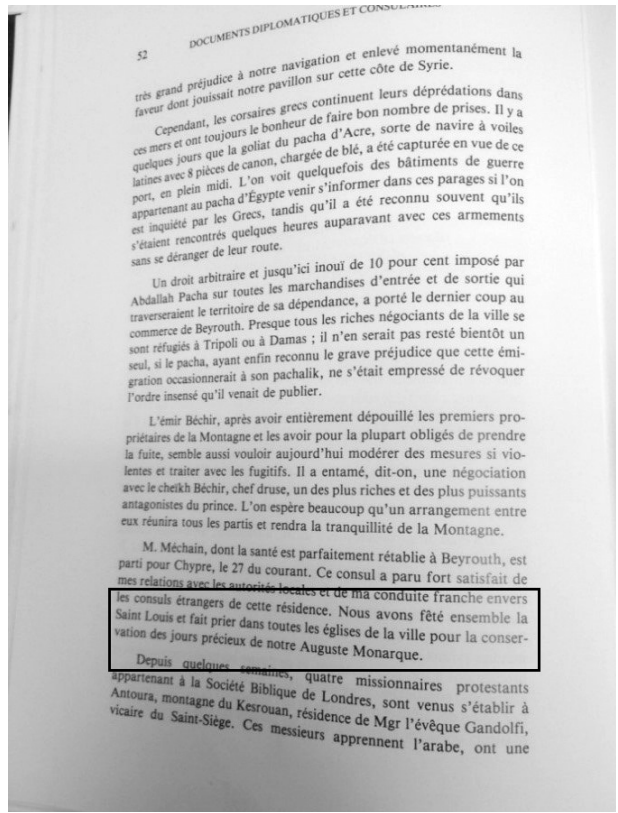

Image 2. The published version of document 1. Translation: We celebrated together the Saint Louis and asked for prayers in all churches of the city for the safeguard of our August Monarch's precious days.

The second document that Ismail worked on, shown below, is missing a paragraph that mentions the return of de Lesseps, Consul General of Aleppo, from the Holy City, where the divine office had been celebrated and the Te Deum, an early Christian hymn of praise in Latin, had been sung. Also included in the omitted paragraph are the words "bishop" and "vicar," terms for senior members of the Christian clergy.

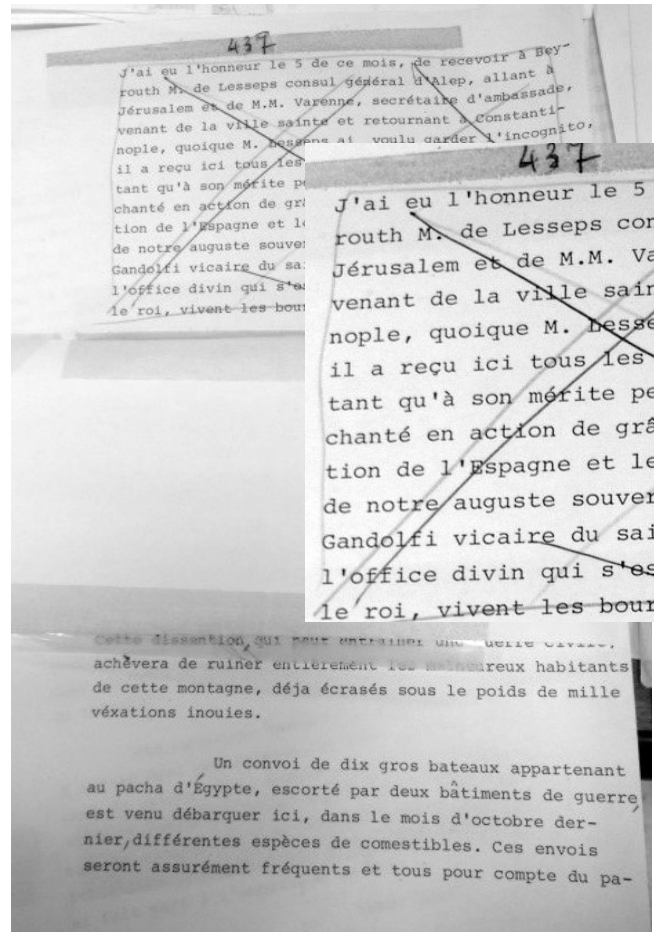

Image 3. Ismail's second transcribed text. ${ }^{40}$

40. Archives de Nantes, consulat de Beyrouth, carton no. 8, Dépêche no. 14. M. Dupont, Drogman, gérant de consulat à Beyrouth, au vicomte de Chateaubriand, ministre des affaires étrangères. Beyrouth, le 30 Septembre 1823. 


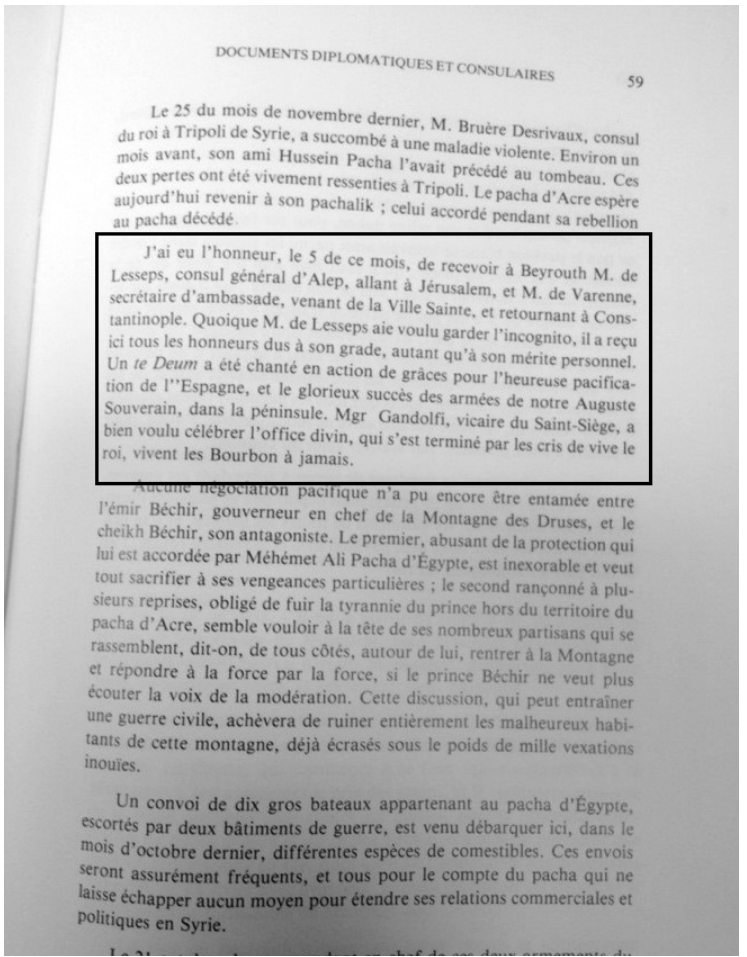

Image 5. The published version of the text, from the 1988 fourvolume set. Translation: I had the honor on the fifth of this month to receive in Beirut Mr. de Lesseps, Consul General of Aleppo [,] and de Varennes, Secretary of the Embassy, coming from the Holy City and returning to Constantinople. [...] A Te Deum was sung as a thanksgiving for the happy pacification of Spain "Bishop Gandolfi, Vicar of the Holy See [,] has kindly celebrated the divine office which ended with shouts, lives the King, live the Bourbons forever" (translation by author)

The content that was previously deleted from the transcribed text had been reinstated in the published version.

This case study unveiled an additional element to the controversy. Following a comparison of the available transcribed documents and editorial notes donated to AUB (represented by images 2 and 5 shown above) with the published version in Ismail's four-volume set of 1988, it appears that the suppressed parts of both documents were reincorporated into the later publication. This suggests that even if Ismail did not publicly admit to inaccuracies in the first publications of 37 volumes,${ }^{41}$ the controversy between the two historians may have played a role in Ismail's reconsidering and reinstating paragraphs he initially had intended to suppress in the 1988 publication, which came out three years after the debate.

\section{Conclusion}

Endangered archives are not only a matter of protecting the physical documents from disasters, wars, or floods; the way one approaches or reveals a hidden collection may harm it. Given the unstable nature of the Middle East, serious steps toward safeguarding primary source documents, preserving the written heritage, and

41. See footnote 32 . 
providing the opportunity of checking the veracity of published works are needed. However, distortion of content and censorship represent threats to this outcome, along with other factors hindering the access to archival material. If Ismail had omitted one phrase from his introduction, "in extenso," explaining the omissions he applied to the original text, he would have avoided a faulty methodological practice and 40 years of undermined work, including collecting, transcribing, and publishing documents relevant to the history of Lebanon.

The situation described above illustrates some of the challenges facing academic libraries, librarians, and archivists in Lebanon in their efforts to safeguard fragments of a dispersed written record of importance to national heritage. It also emphasizes the role played by academic private institutions in making a variety of collections accessible to the generations of students and researchers to come. The paper also witnesses the importance of primary sources, which represent evidence of the past, as well as the importance of ascertaining their integrity. At a later stage, a new project is anticipated that is rooted in the situation described here, whose goal is to establish an index of archival material on Lebanon available both locally and abroad. 